Gut, 1987, 28, S1, 37-43

\title{
Proliferative effects of urogastrone-EGF on the intestinal epithelium
}

\author{
R A GOODLAD, T J G WILSON, W LENTON, H GREGORY, \\ K G MCCULLAGH, AND N A WRIGHT \\ From the Cancer Research Campaign Cell Proliferation Unit, Department of Histopathology, Royal \\ Postgraduate Medical School, Hammersmith Hospital, London, ICI, Alderley Park, Macclesfield, \\ and G D Searle, High Wycombe, Bucks
}

SUMMARY The effects of B-urogastrone/human epidermal growth factor on intestinal epithelial cell proliferation were studied in rats in which intestinal cell proliferation was reduced to a steady state basal level (by maintaining the rats on total parenteral nutrition). Increasing doses of urogastrone progressively raised the two hour collection of metaphases and intestinal weights. The crypt cell production rate was measured in animals maintained parenterally with or without urogastrone, and in rats fed a standard laboratory ration. Continuous infusion of $15 \mu \mathrm{g}$ per rat per day of recombinant beta urogastrone (a dose which has a minimal effect on gastric acid secretion) significantly increased cell proliferation and intestinal tissue weights throughout the gastrointestinal tract. Intravenous infusion of urogastrone was also effective in restoring cell proliferation when it was infused after the intestine had become hypoproliferative. Urogastrone administered through an intragastric cannula thrice daily had no significant effect on either intestinal weight, crypt cell production rate, or metaphase collection.

$\beta$-urogastrone (human epidermal growth factor, URO-EGF) is a natural human polypeptide which has similar properties to rat and mouse EGF. ${ }^{12}$ While the growth promoting actions of URO-EGF in vitro have been well characterised, ${ }^{3}$ its role in vivo is uncertain: URO-EGF stimulates the proliferation and maturation of the neonatal intestine,${ }^{4-6}$ where it also increases the activity of intestinal ornithine decarboxylase. ${ }^{7}$ The presence of URO-EGF in a variety of body fluids, including saliva, plasma $^{3}$ and milk, ${ }^{8}$ its production by the salivary and Brunners glands, ${ }^{910}$ the demonstration of URO-EGF receptors in intestinal epithelial cells ${ }^{112}$ and its reported cytoprotective effects on the duodenal mucosa, ${ }^{13}$ all suggest that it has a role in the control of gastrointestinal homeostasis-quite apart from its ability to inhibit gastric acid secretion. ${ }^{14}$

Previous studies of the effects of URO-EGF on the intestine have yielded conflicting results ${ }^{15-21}$ which could be due to the use of inappropriate animal

Address for correspondence: Dr R A Goodlad, Dept of Histopathology, Royal Postgraduate Medical School (RPMS), Hammersmith Hospital, Ducane Road, London. models. The best model is probably the rat maintained by isocaloric total parenteral nutrition (TPN), ${ }^{22}$ as the intestine of the TPN rat is in a steady state at a basal level of cell proliferation, so that the direct and indirect effects of food (luminal nutrition), and the effects of endogenous secretions, are considerably reduced.

This model was used to investigate the effects of recombinant URO-EGF on cell proliferation in five experiments. The first was a dose response study. The second quantified the effects of an intravenous dose of URO-EGF on crypt cell production rate in a maintenance experiment. ${ }^{23}$ The third experiment investigated the time course of the effects of UROEGF when given after the intestine had atrophied (intervention). The fourth and fifth investigations studied the effects of the intragastric administration of URO-EGF.

URO-EGF stimulated intestinal epithelial cell proliferation and growth at all sites of the gastrointestinal tract, in a dose dependent manner, the most marked effects being observed in the stomach and colon. A relatively low dose of URO-EGF, which should not inhibit gastric acid secretion, significantly 

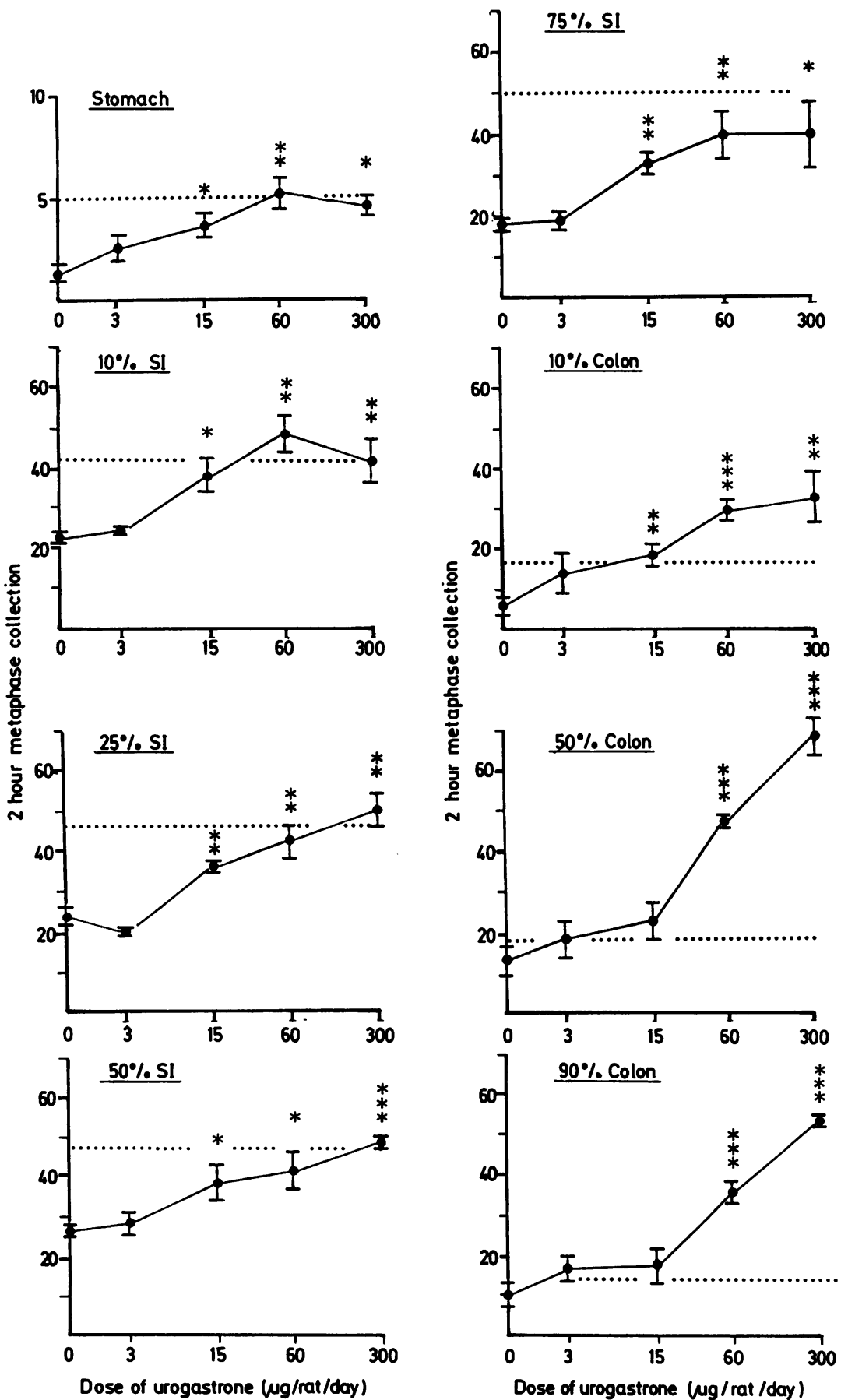

Fig. 1 Effects of 10 days intravenous infusion of various doses of urogastrone on 2-hour metaphase collection. Sites were defined by their position in the gut (as percentage length of the small intestine or colon), thus $10 \% \mathrm{SI}=10 \%$ of the length of the small intestine. The dotted line shows the values obtained in orally fed rats. There were 4 animals per group.

${ }^{*}=$ significantly higher than the TPN group $p<0.05 ;{ }^{* *}=$ significantly higher than the TPN group $p<0.01$;

*** = significantly higher than the TPN group $p<0.001$. 
increased the crypt cell production rate (CCPR) throughout the intestine, with the CCPR's of the stomach and colon increasing to the levels observed in orally-fed rats. URO-EGF was also effective in stimulating proliferation, once hypoplasia had become established. Intragastric administration, however, had no effect.

\section{Methods}

\section{URO-EGF}

The URO-EGF was recombinant polypeptide (supplied by ICI and GD Searle) derived from the expression of a synthetic gene in $E$ coli $^{24}$ and purified to $>97 \%$. It had the same amino acid sequence and biological activity as natural human URO-EGF.

\section{ANIMALS}

Male $200 \mathrm{~g}$ Wistar rats (Olac Ltd., Blackthorn, Oxon, UK) were housed individually in wire bottomed Perspex cages made up in the RPMS workshops. The rats were maintained on the respective treatments for 10 days, unless stated otherwise. Rats were anaesthetised and the right external jugular vein cannulated with a silastic catheter, which was brought round to the back of the neck by a skin tunnel and connected via a Harvard skin button and stainless steel tether (Harvard Apparatus Ltd, Fircroft Way, Kent, UK) to a Harvard miniature fluid swivel joint. ${ }^{22}$

\section{TPN DIET}

One litre of the diet contained the following: $714 \mathrm{ml}$ Vamin glucose, $92 \mathrm{ml}$ intralipid $20 \%$ (Kabivitrum Ltd, Riverside Way, Uxbridge) $140 \mathrm{ml}$ dextrose $50 \%$, vitamins and salts. Each rat was infused with $60 \mathrm{ml} /$ day giving $1.8 \mathrm{~g} \mathrm{~N}$, as purified amino acids, equivalent to $11.5 \mathrm{~g}$ of first class protein; $6.0 \mathrm{~g}$ lipid; $8.5 \mathrm{~g}$ glucose and $250 \mathrm{kcal}$ per $\mathrm{kg}$ of rat per day.

\section{AUTOPSY PROCEDURE}

The rats were given $1 \mathrm{mg} / \mathrm{kg}$ vincristine sulphate (Eli Lilly, Basingstoke, UK) intravenously, and killed at timed intervals by injection of $12 \mathrm{mg}$ of pentobarbitone and exsanguination. The stomach, caecum and samples of the small intestine and colon (as defined by their percentage length) were then weighed and fixed in Carnoy's fluid. The tissue was stained with the Feulgen reaction and the antral glands, intestinal crypts or colonic crypts were microdissected; the number of arrested metaphases in ten crypts was then counted and the mean values plotted against time after injection. The slope of the line, fitted by least squares linear regression, gave the crypt cell production rate (CCPR). ${ }^{25}$ For some studies the accumulation of metaphases over a two hour period was quantified to give an augmented mitotic index.

\section{Results}

INTRAVENOUS UROGASTRONE DOSE RESPONSE STUDY

The effects of 0 to $300 \mu \mathrm{g} / \mathrm{rat} /$ day of URO-EGF on the two hour collection of arrested metaphases were determined in a dose response study in parenterally maintained rats.

There was a highly significant $(\mathrm{p}<0.001)$ correlation $(r=0.997)$ between plasma URO-EGF and the dose of URO-EGF administered. Plasma URO-EGF rose by $37.8 \pm 1.2 \mathrm{pg} / \mathrm{ml}$ per $\mu \mathrm{g}$ administered per rat per day.

There was no evidence of any effect at the lowest dose (3 $\mu \mathrm{g} / \mathrm{rat} /$ day) (Fig. 1), however, there were significant increases with the $15 \mu \mathrm{g} / \mathrm{rat} /$ day group in all the intestinal sites studied except the mid and distal colon. This proliferative response continued in a dose responsive manner in most sites. The most pronounced effects were seen in the colon.

INTRAVENOUS UROGASTRONE (MAINTENANCE)

A dose of $15 \mu \mathrm{g} / \mathrm{rat} /$ day was chosen for an investigation utilising the crypt cell production rate (CCPR) method. The aim of the study was to investigate whether continuous infusion of URO-EGF, at a dose below that needed to inhibit gastric acid secretion, could maintain epithelial cell proliferation at the levels observed in orally-fed rats when the rats were fed parenterally.

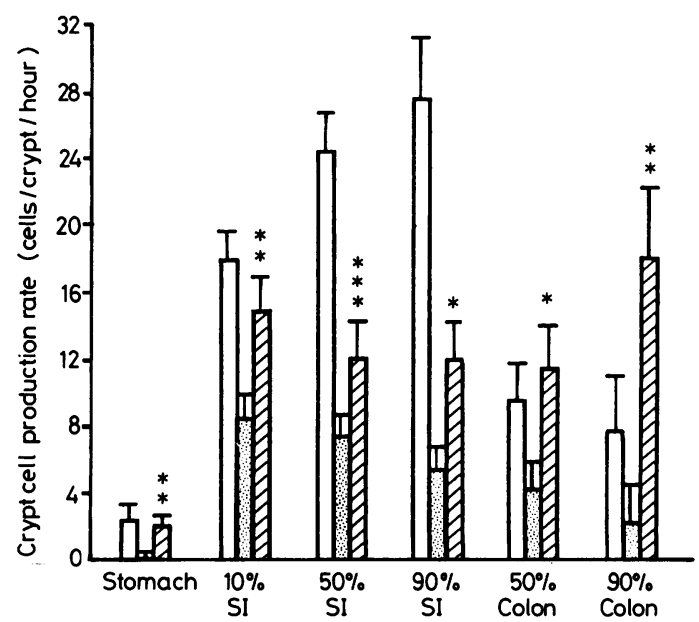

Fig. 2 Effects of oral feeding, TPN or TPN plus urogastrone $(15 \mu \mathrm{g} / \mathrm{rat} /$ day $)$ on crypt cell production rates. Open bars $=$ orally-fed rats $(n=10)$, stippled bars $=T P N$ rats $(n=8)$, hatched bars $=T P N+$ urogastrone $(n=10)$. Rats were given their respective diets for 10 days.

* = significantly higher than the TPN group $p<0.05$; ** = significantly higher than the TPN group $p<0.01$; *** = significantly higher than the TPN group $p<0.001$. 

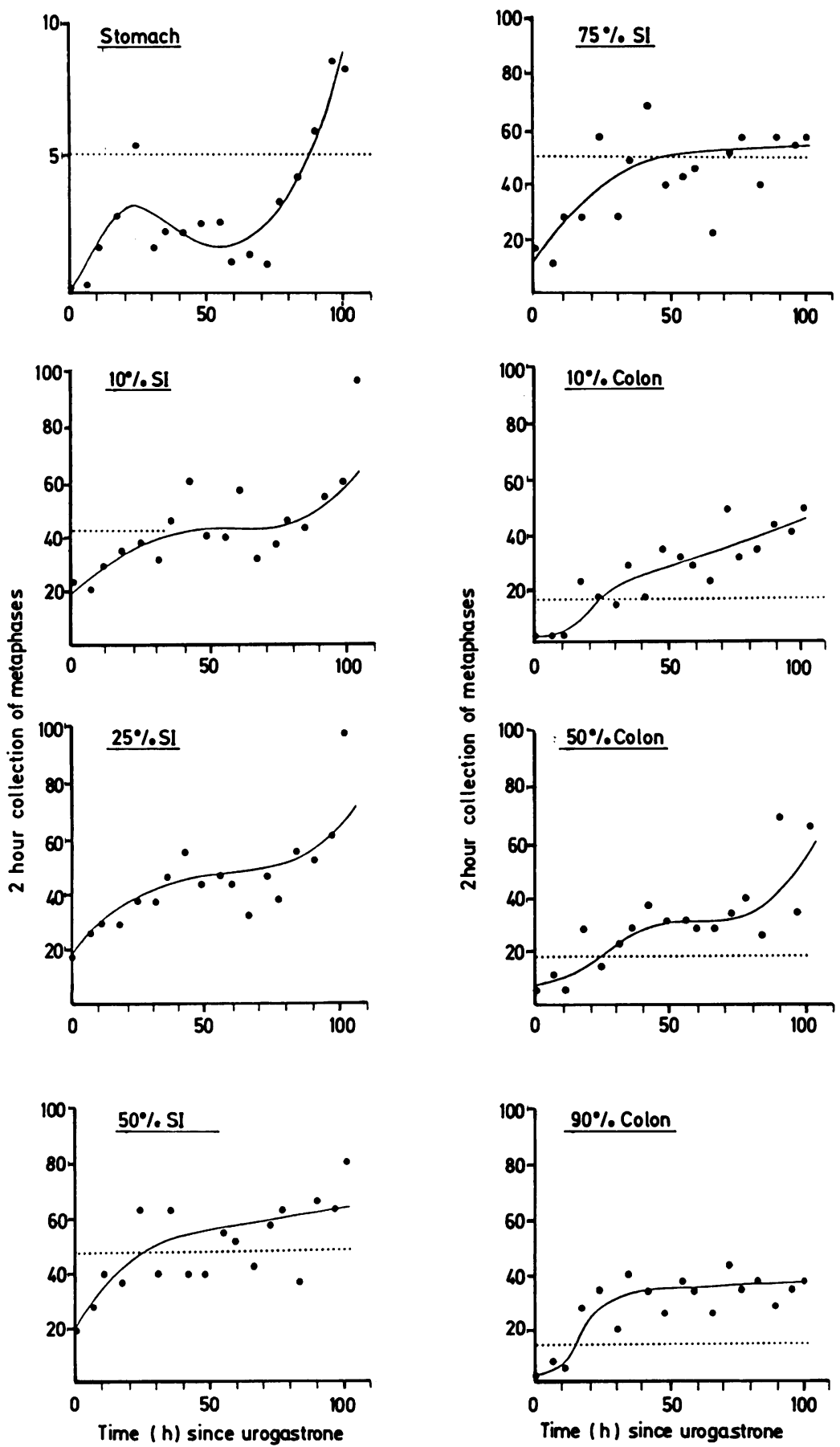

Fig. 3 Two hour metaphase collection (mean value for 10 crypts or glands) at various times after the administration of urogastrone $(60 \mu \mathrm{g} / \mathrm{rat} /$ day). The sites were defined by the relative length of the small intestine (SI) and of colon. Rats were maintained by TPN for 4 days before the infusion of urogastrone. Dotted line shows the values obtained in orally fed rats. 
Ten days of TPN significantly decreased $(p<0.01)$ the weights of the small intestine, caecum and colon and the CCPR (Fig. 2). $15 \mu \mathrm{g} / \mathrm{rat} /$ day of URO-EGF, infused intravenously, gave a mean plasma level of $1085 \pm 276 \mathrm{pg} / \mathrm{ml}$ and significantly increased the relative weight of the stomach, small intestine and colon, when compared with the TPN group ( $\mathrm{p}<0.01,0.001$, 0.05 ), and significantly increased the CCPR at all sites in the gastrointestinal tract (Fig. 2).

\section{INTERVENTION TIME COURSE STUDY}

An intervention study was instigated in order to determine whether URO-EGF could also cause a proliferative response in the atrophic intestine, and if so, to investigate the time course of this response. Rats were maintained on TPN for four days, then given $60 \mu \mathrm{g} / \mathrm{rat} /$ day URO-EGF and killed at six hour intervals. Proliferation was quantified by the two hour collection of arrested metaphases. There was a general increase in tissue weights with time, and this was statistically significant (by analysis of variance) for the small intestine $(p<0.05)$ and the colon $(p<0.01)$. The effects of urogastrone on the accumu- lation of arrested metaphases is shown in Fig 2. There was a gradual increase in metaphases over the first 24 hours, becoming apparent 12 hours after the administration of urogastrone in the stomach and small intestine. There was, however, no evidence of increased cell proliferation in the colon until 18 hours after the administration of urogastrone.

\section{INTRAGASTRIC ADMINISTRATION OF UROGASTRONE}

The effects of intragastric infusion of URO-EGF were investigated. A tube was placed in the squamous stomach of the rats at the time of their jugular cannulation. This tube was then used to infuse UROEGF at eight hour intervals. The CCPR was measured after 10 days of daily dosing with urogastrone at $15 \mu \mathrm{g} / \mathrm{rat} / \mathrm{day}$.

A further intragastric study was also carried out in which higher doses of URO-EGF (150 and $300 \mu \mathrm{g} /$ rat/day) were used, incorporating the two hour metaphase arrest method. The daily intragastric infusion of $15 \mu \mathrm{g}$ of urogastrone per rat had no effect on intestinal weight. The CCPR of the various

Table 1. Effects of intragastric urogastrone (15 $\mu \mathrm{g} /$ rat $/$ day) crypt cell production rates.

\begin{tabular}{lllll}
\hline & Controls & \pm & +URO-EGF & \pm \\
\hline $\begin{array}{l}\text { Stomach } \\
10 \% \text { of the length of } \\
\text { small intestine }\end{array}$ & 0.59 & 0.24 & 0.38 & 0.56 \\
$\begin{array}{l}50 \% \text { of the length of } \\
\text { small intestine }\end{array}$ & 7.50 & 1.58 & 11.03 & 4.33 \\
$\begin{array}{l}90 \% \text { of the length of } \\
\text { small intestine }\end{array}$ & 5.63 & 1.35 & 11.25 & 2.53 \\
$\begin{array}{l}50 \% \text { of the length of } \\
\text { colon }\end{array}$ & 7.28 & 0.83 & 13.01 & 4.53 \\
$\begin{array}{l}90 \% \text { of the length of } \\
\text { colon }\end{array}$ & 2.92 & 1.44 & 5.00 & 1.08 \\
\hline
\end{tabular}

There were 7 animals per group. The rats were on TPN (with or without URO-EGF) for 10 days.

Table 2. Effects of high doses of urogastrone (150 and $300 \mu \mathrm{g} / \mathrm{rat} /$ day) on the 2-hour collection of metaphases.

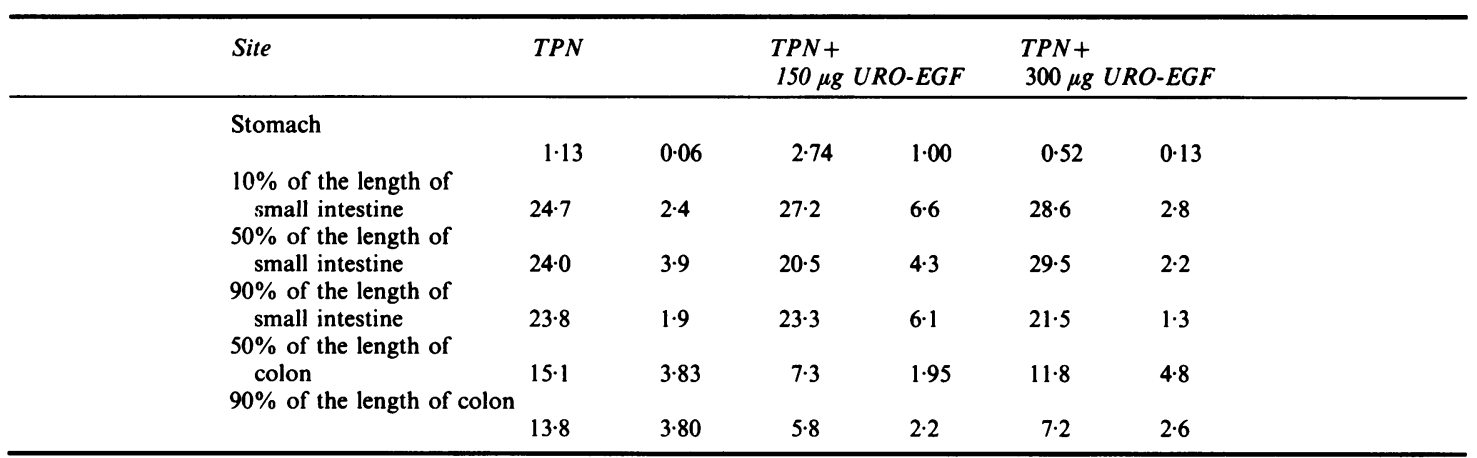

The treatments lasted for 10 days. There were 4 animals in the control group, 5 in the $150 \mu \mathrm{g} / \mathrm{rat} /$ day group and 4 in the $300 \mu \mathrm{g} / \mathrm{rat} /$ day group. 
intestinal sites is shown in Table 1 and although the CCPR appeared to be greater in the urogastrone treated group, no significant differences were obtained.

Luminal administration of higher doses of urogastrone also had no effect on either (i) the weight of the intestine or (ii) the two hour metaphase accumulation (Table 2).

\section{Discussion}

The dose of urogastrone used in the maintenance study $(15 \mu \mathrm{g} / \mathrm{rat} /$ day $)$ was considerably less than that used by most previous workers, ${ }^{5-7151618}$ and should only have had a minor influence on gastric acid secretion. ${ }^{1426}$ This dose was, nonetheless, twice that used by some other workers ${ }^{171921}$ whose results were somewhat equivocal in terms of the responses observed. However, these studies used starved animals, which are not an ideal model for proliferative studies.

The increase in proliferation in the intervention study was seen in the stomach and small intestine after 12 hours but in the colon only after 18 hours. Similar differences in the time course of proliferative increase have been observed in the intestine of starved mice after refeeding, ${ }^{27}$ which implied that the delay in colonic response was the consequence of the greater time taken for digesta to reach the colon. The present results suggest, however, that this delay reflects some inherent difference between the colon and the stomach-small intestine; perhaps due to the longer cell cycle time. ${ }^{2829}$

The intragastric infusion of various doses of urogastrone had no significant effect on intestinal weights, CCPR or two hour metaphase collection. Although URO-EGF is taken up by the digestive tract in the neonate and weanling rat, ${ }^{30}$ recent evidence suggests that it is not absorbed in the adult gut. $^{31}{ }^{32}$ Whilst intragastric URO-EGF may have a cytoprotective action in the damaged gastric mucosa ${ }^{13}$ the intestine was not damaged in this study.

The mechanisms or significance of the in vivo trophic action of URO-EGF are as yet unknown. Gastrointestinal epithelial cells possess URO-EGF receptors ${ }^{1112}$ and the lack of response to luminal URO-EGF would suggest that they are located on the baso-lateral surface. It is also possible that these actions are mediated by another hormone or factor.

The present study has confirmed that TPN is associated with profound intestinal hypoplasia resulting in a new 'steady state'. We have quantified this in terms of crypt cell production. We have also shown that urogastrone was effective in reducing this hypoproliferative state, either when given during the initiation of TPN-associated hypoplasia (mainten- ance) or when hypoplasia had become established (intervention). These results suggest that URO-EGF could play an important role as a trophic factor in the maintenance of epithelial proliferation in the gastrointestinal tract.

We thank the Cancer Research Campaign for financial assistance.

\section{References}

1 Gregory $\mathrm{H}$. Isolation and structure of urogastrone and its relationship to epidermal growth factor. Nature (Lond) 1975; 257: 325-7.

2 Carpenter G, Cohen S. Epidermal growth factor. Ann Rev Biochem 1979; 48: 193-216.

3 Carpenter G. Epidermal growth factor. In: Baserga R, ed. Tissue growth factors. Berlin: Springer-Verlag, 1981 : 89-123.

4 Malo C, Menard D. Influence of epidermal growth factor on the development of suckling mouse intestinal mucosa. Gastroenterology 1982; 83: 28-35.

5 Oka Y, Ghrisan FK, Greene HL, Orth DN. Effect of mouse epidermal growth factor/urogastrone on functional maturation of rat intestine. Endocrinology 1983; 112: $940-4$.

6 Calvert R, Beaulieu JF, Menard D. Epidermal growth factor EGF : accelerates the maturation of foetal mouse intestinal mucosa in utero. Experientia 1982; 38: 1096.

7 Feldman EJ, Aures D, Grossman MI. Epidermal growth factor stimulates Ornithine Decarboxylase activity in the digestive tract of the mouse. Proc Soc Exp Biol Med 1978; 159: 400-2.

8 Carpenter G. Epidermal growth factor is a major growth promoting agent in human milk. Science 1980; 210: 198-9.

9 Heitz PU, Kasper M, Van Noorden S, Polak JM, Gregory H, Pearse AGE. Immunohistochemical localisation of urogastrone to human duodenal and submandibular glands. Gut 1978; 19: 408-13.

10 Olsen PS, Nexo E. Quantitation of epidermal growth factor in the rat: Identification and partial characterisation of duodenal EGF. Scand J Gastroenterol 1983; 18: $771-6$.

11 Forgue-Lafitte ME, Laburthe M, Chambblier MC, Moody AJ, Rosselin G. Demonstration of specific receptors for EGF/urogastrone in isolated rat intestinal epithelial cells. FEBS Lett 1980; 114: 243-6.

12 St Hilaire RJ, Gospodarowicz D, Kim YS. Epidermal growth factor: effect on the growth of a human colon adenocarcinoma cell line. Gastroenterology 1981; 78: 1271.

13 Kirkegaard P, Olsen PS, Poulsen SS, Nexo E. Epidermal growth factor inhibits Cysteamine-induced duodenal ulcers. Gastroenterology 1983; 85: 1277-83.

14 Bower JM, Camble R, Gregory H, Gerring EL, Willshire IR. The inhibition of gastric acid secretion by epidermal growth factor. Experientia 1975: 31 : 825-6.

15 Schieving LA, Yeh YC, Scheiving LE. Circadian phasedependant stimulatory effects of epidermal growth factor on deoxyribonucleic acid synthesis in the tongue, 
oesophagus, and stomach of the adult male mouse. Endocrinology 1979; 105: 1475-80.

16 Schieving LA, Yeh YC, Tsai TH, Scheiving LE. Circadian phase-dependant stimulatory effects of epidermal growth factor on deoxyribonucleic acid synthesis in the duodenum, jejunum, ileum, caecum, colon and rectum of the adult male mouse. Endocrinology 1980; 106: 1498-503.

17 Johnson LR, Guthrie PD. Stimulation of rat oxyntic gland mucosal growth by epidermal growth factor. $\mathrm{Am}$ J Physiol 1980; 238: G45-G9.

18 Chabot JG, Paget N, Hugon JS. Effects of epidermal growth factor EGF: on adult mouse small intestine in vivo and in organ culture. Comp Biochem Physiol 1983; 74: 247-52.

19 Dembinski A, Gregory H, Konturek SJ, Polanski M. Trophic action of epidermal growth factor on the pancreas and gastroduodenal mucosa in rats. $J$ Physiol (Lond) 1982 ; 325: 35-42.

20 Majumdar APN. Postnatal undernutrition: Effects of epidermal growth factor on growth and function of gastrointestinal tract in rats. $J$ Pediatr Gastroenterol Nutr 1984; 3: 618-25.

21 Al-Nafussi A, Wright NA. The effect of epidermal growth factor EGF: on cell proliferation of the gastrointestinal mucosa of rodents. Virchows Arch [Cell Pathol] 1982; 40: 63-9.

22 Hughes CA, Dowling RH. Speed of onset of adaptive mucosal hypoplasia and hypofunction in the intestine of parenterally fed rats. Clin Sci 1980; 59: 317-27.

23 Goodlad RA, Wilson TGJ, Lenton W, Gregory H, McCullough KG \& Wright NA. Urogastrone-epidermal growth factor is trophic to the intestine of parenterally fed rats. Experientia 1985; 41: 1161-3.
24 Smith J, Cook E, Fotheringham I et al. Chemical synthesis and cloning of a gene for human B-urogastrone. Nucleic Acid Res 1982; 10: 4467-82.

25 Goodlad RA, Wright NA. Quantitative studies on epithelial replacement in the gut. In: Titchen $\mathrm{T} A$, ed. Techniques in the life sciences. Techniques in digestive physiology. Vol P2. Ireland: Elsevier Biomedical Press, 1982: 212/1-23.

26 Konturek SJ, Radecki T, Brzozowski T et al. Gastric cytoprotection by epidermal growth factor: role of endogenous prostaglandins and DNA synthesis. Gastroenterology $1981 ; 81$ : 433-45

27 Goodlad RA, Wright NA. The effects of starvation and refeeding on intestinal cell proliferation in the mouse. Virchows Arch B 1984; 45: 63-73.

28 Brooks RF, Bennett DG, Smith JA. Mammalian cell cycles need two random transitions. Cell 1980; 19: 493504.

29 Hagemann RF, Stragand JJ. Fasting and refeeding: Kinetic response of jejunum, ileum and colon. Cell Tiss Kinet 1977; 10: 3-14.

30 Thornburg W, Matrisian L, Magun B, Koldovsky O. Gastrointestinal absorption of epidermal growth factor in suckling rats. Am J Physiol 1984; 246: G80-5.

31 Skov P, Olsen SS, Poulsen P, Kirkegaard P, Nexo E. Does urinary epidermal growth factor EGF: originate from the gastrointestinal tract? Dig Dis Sci 1984; 29: 615.

32 Olsen PS, Poulsen SS, Kirkegaard P, Nexo E. Role of submandibular saliva and epidermal growth factor in gastric cytoprotection. Gastroenterology 1984; 87: 1038. 